\title{
Studies on the frequency of the taste-blindness for some substances among the Japanese people
}

\section{Akio SuZuki (跉木 炤火)}

Concerning to the taste in man, the frequency of the taste-blindness and their hereditary type were quickly discovered since Fox (1931) first found out the individual differences in the senses of taste for P.T.C. (Phenyl Thio Carbamide). Afterwards it was confirmed that the individual differences in senses of taste is not only due to P.T.C., but also due to the majority of its derivatives, such as para ethoxy phenyl thio carbamide, A.N.T.U. ( $\alpha$ naphthyl thio urea), etc., di phenyl guanidine, famar protocetralic acid, cetralic acid and mannose have been discovered.

In the present paper the author has studied on the individual differences in senses of taste for some substances in connection to the frequency of the taste-blindness which may be found among the Japanese people.

\section{Date and Result}

The results of taste testings obtained during this survey were used as the basic data for the present studies. The data was obtained from the primary and middle school children in Tokorosawa (in Saitama Pref.) and Ohme (in Tokyo). It was secured by the method of questioning of which each child would write on a printed card to record each difference in senses of taste. The substances given were 1) Sodium Benzoate $\left(\mathrm{C}_{;} \mathrm{H}_{5} \mathrm{COONa}\right)$ 2) A.N.T.U. $\left(\mathrm{C}_{3} \mathrm{H}_{5} \mathrm{NHCSNH}_{2}\right)$ and 3) Mannose $\left(\mathrm{C}_{;} \mathrm{H}_{1_{2}} \mathrm{O} ;\right)$ and the results are the following:--

\section{Taste for Sodium Benzoate}

The frequency of the individual differences in sense for the taste of Sodium Benzoate is generally believed to be no taste by the majority of people but a few may find it bittler. Table I shows the result of investigation on the individual differences in senses of taste for this substances based on the 794 Japanese. It is surprising that the majority of people felt some kind of a taste (about $85 \%$ ), the frequency of the bittler for the male is $12.56 \%$ while $11.82 \%$ for the female, no sexual difference could be detected.

II Taste for A.N.T.U.

a) Frequency of the individual differences in senses of taste

A.N.T.U. is well known as a rat killing powder. Takugi (1948) shows that the 
frequency of the taste-blindness for A.N.T.U. among 915 Japanese in Toyohashi City (in Aichi Pref.) is $33 \%$ which value is less than that found among the Americans. Table II shows the result of investigation on the individual differences in senses of taste for A.N.T.U. for the 813 Japanese. The result is that the majority of peoples felt bittler (about 78\%) and the frequency of the taste-blindness is also less than the former experiment. There are $6.75 \%$ in the male while $6.58 \%$ in the female.

b) The sexual difference

In Table III the sexual difference in the frequency of the taste-blindness is shown. According to Takugi ('48) the sexual difference could not be observed, as shown in Table III, from the result of $\mathrm{x}^{2}$ test the difference is large enough to be statistically significant.

c) The difference according to age

As shown below the incidence of the lack of ability is considerably different according to the age (Table IV). It is very high among young children and it decreases with age (Takugi 1948). Takugi published the result on this study carried out upon students of a high school in Toyohashi City. In table $\mathrm{V}$ shows the data obtained from the children of the primary and the middle schools; although this table is incomplete it nevertheless shows the age differences.

\section{Taste for Mannose}

a) The Frequency of the individual differences in senses of taste

Mannose is well known as the sweetness and usually it feels sweet. Table VI shows the result of investigation on the individual differences in senses of taste for this substances for 1948 Japanese. The frequency of the taste-blindness in the male is $1.7 \%$ while $0.8 \%$ in the female.

b) The sexual difference

Table VII shows the sexual difference in the frequency of the taste-blindness in the male which invariably shows a higher incidence than that of the female. This difference is not large enough to be statistically significant.

Table I Showing the 1ndividual differences in senses of taste for Sodium Benzoate

\begin{tabular}{c|c|c|c}
\hline \multirow{2}{*}{$\%$} & \multicolumn{3}{|c|}{ 794 Japancse } \\
\cline { 2 - 4 } & 옹 406 & 우 388 & Total \\
\hline Tasteless & 2.72 & 1.59 & 2.15 \\
\hline Bittler & 12.56 & 11.82 & 12.19 \\
\hline Others & 84.72 & 86.59 & 85.65
\end{tabular}

Table II Showing the individual differences in senses of taste for A.N.T.U.

\begin{tabular}{|c|c|c|c|}
\hline \multirow{2}{*}{$\%$} & \multicolumn{3}{|c|}{813 Japanese } \\
\hline & 今 417 & 우 396 & Total \\
\hline Tastelcss & 6.75 & 6.58 & 6.65 \\
\hline Bittler & 81.77 & 72.97 & 77.37 \\
\hline Others & 11.48 & 20.45 & 15.98 \\
\hline
\end{tabular}


Table III Showing the sexual difference in the frequency of the taste-blindness

\begin{tabular}{|c|c|c|c|c|}
\hline Sex & Taster & Tasteless & Total & of Tasteless \\
\hline$\widehat{\delta}$ & $\frac{514}{(529.0)^{*}}$ & $\frac{61}{(46.1)}$ & 575 & $10.60 \%$ \\
\hline \multirow{2}{*}{ 오 } & 508 & 30 & 538 & $5.57 \%$ \\
\hline & $(49.3)$ & $(45.9)$ & & \\
\hline Total & 1022 & 91 & 1113 & $8.80 \%$ \\
\hline$* \exp$ & ted & $x^{2}=9.376$ & & $(0.01$ \\
\hline
\end{tabular}

Table IV Difference accorcing to age by Takugi (1948)

\begin{tabular}{c|r|r|r|rr}
\hline Ago & Taster & $\begin{array}{c}\text { Taste- } \\
\text { less }\end{array}$ & Total & $\begin{array}{c}\% \text { of } \\
\text { Tasteless }\end{array}$ \\
\hline $6-10$ & 38 & 27 & 65 & 42 & $\%$ \\
$11-15$ & 85 & 48 & 193 & 36 & $\%$ \\
$16-20$ & 273 & 72 & 345 & 21 & $\%$ \\
$21-25$ & 80 & 16 & 96 & 15 & $\%$ \\
26 over & 229 & 48 & 277 & 17 & $\%$ \\
\hline Total & 705 & 211 & 916 & 23 & $\%$
\end{tabular}

Table V Difference according to age

\begin{tabular}{c|r|r|r|r}
\hline Age & Taster & $\begin{array}{c}\text { Taste- } \\
\text { less }\end{array}$ & Total & $\begin{array}{c}\% \text { of } \\
\text { Tasteless }\end{array}$ \\
\cline { 2 - 5 } $6-10$ & 215 & 38 & 253 & $15.02 \%$ \\
$11-15$ & 797 & 53 & 850 & $6.23 \%$ \\
\hline Total & 1012 & 91 & 1103 & $10.62 \%$
\end{tabular}

Table VI Showing the individual differences in senses of taste for Mannose

\begin{tabular}{|c|c|c|c|}
\hline \multirow{2}{*}{ \% } & \multicolumn{3}{|c|}{1498 Japanese } \\
\hline & 今 713 & 우 785 & Total \\
\hline Tasteless & 1.69 & 0.77 & 1.20 \\
\hline Sweet & 48.94 & 43.82 & 45.65 \\
\hline Bittler & 6.73 & 5.73 & 6.20 \\
\hline Sweet \& Bi & 42.64 & 49.68 & 46.95 \\
\hline
\end{tabular}

Table VII Sexual difference in the frequency of the taste-blindness

\begin{tabular}{|c|c|c|c|c|}
\hline Sex & Taster & $\begin{array}{c}\text { Taste- } \\
\text { less }\end{array}$ & Total & $\begin{array}{l}\text { \%o of } \\
\text { Tasteless }\end{array}$ \\
\hline \multirow{2}{*}{$\widehat{\delta}$} & 701 & 12 & 713 & $1.69 \%$ \\
\hline & $(704.4)$ & (8.8) & & \\
\hline \multirow{2}{*}{ 오 } & 779 & 6 & 785 & ().77\% \\
\hline & $(775.4)$ & $(9.4)$ & & \\
\hline Total & 1480 & 18 & 1498 & 1.20 年 \\
\hline
\end{tabular}

$\mathrm{x}^{2}-2.654 \quad x>0.10$

\section{Summary}

1. The author studied on the individual differences in senses of taste for some substances with special reference to the frequency of the taste-blindness among the Japanese people.

2. Sodium Benzoate $\left(\mathrm{C}_{3} \mathrm{H}_{5} \mathrm{COONa}\right)$ gives some kind of a taste to the majority of people (about 75\%) and the frequency of the taste-blindness is about $2.8 \%$ in the male and $1.16 \%$ in the female, and the frequency of the bittler shows $12.56 \%$ in the male while $11.82 \%$ in the female. 
3. A.N.T.U. $\left(\mathrm{C}_{;} \mathrm{H}_{5} \mathrm{NHCSNH}_{2}\right)$ gives a strong bittertaste to people (about $78 \%$ ) and the frequency of its taste-blindness is about $6.8 \%$ in the male and $6.6 \%$ in the female. The ability thus shows a distinct sexual difference and also considerably according to the age.

4. Mannose $\left(\mathrm{C}_{;} \mathrm{H}_{12} \mathrm{O}_{3}\right)$ gives sweet taste and a sweet and bit taste and the frequency of the taste-blindness shows about $1.7 \%$ in the male while $0.8 \%$ in the female.

The above results show the individual differences in senses of taste given substances is dne to the racial difference in the frequency of the gene.

In conclusion the author wishes to express his thanks to Mr.C.Nakatani and Mr. Y. Shiono who kindly sent materials for his use.

\section{Literature cited}

Fukuoka, G. 1036 On the frequency of taste-blindness among the Mongolian races. Jap. Jour. Genet. 12

Komatsu, I. 1948 On the phenomena of taste-blindness (Japanese). Race Hygiene 15

Takugi, K. 1948 On the individual differences of taste (Japanese). Kagaku 18

Tanaka, Y. 1948 Genetics (Japanese).

Tanaka, Y. 1950 On the inheritance of taste-blindness (Japanese). Iden 4

摘

要

筆者は日本人に於ける数種薬品に対寸る味覚の個人善殊に味盲の頻度を調べた。その結果, 安息香酸ソー ダは一般に無味とされているが㬰際は何かの味を与え，苦味を感ずる人は男子で $12.56 \%$ ，女子では $11.82 \%$ である。次に殺単剤 A.N.T.U. では多くの人に苦味を与え，味盲者の頻度は罗子で $6.75 \%$ ，女子では 6.58\% であつて，この值は米国人及豊橋市日本人の味盲頻度より遥かに小さい。文性差及で年令による差も明瞭に 認められたた。又マンノーズでは多くの人に甘味及で苦味と甘味の混合味を与える。味盲頻度は男子は女子よ り大で $1.7 \%$ ，女子は $0.7 \%$ を示した。以上の事より味覚の個人羑特に味盲の頻度は人種により又地域に 上り多少の差が認められるのを知る。 